\title{
Therapeutic mechanism of treating SMMC-7721 liver cancer cells with magnetic fluid hyperthermia using $\mathrm{Fe}_{2} \mathrm{O}_{3}$ nanoparticles
}

\author{
S.Y. Yan ${ }^{1}$, M.M. Chen ${ }^{1}$, J.G. Fan ${ }^{1}$, Y.Q. Wang ${ }^{1}$, Y.Q. $\mathrm{Du}^{2}$, Y. $\mathrm{Hu}^{1}$ and L.M. $\mathrm{Xu}^{1}$ \\ ${ }^{1}$ Department of Gastroenterology, Xinhua Hospital, Shanghai Jiaotong University School of Medicine, Shanghai, China \\ ${ }^{2}$ Department of Pathology, Cancer Hospital, Fudan University, Shanghai, China
}

\begin{abstract}
This study aimed to investigate the therapeutic mechanism of treating SMMC-7721 liver cancer cells with magnetic fluid hyperthermia (MFH) using $\mathrm{Fe}_{2} \mathrm{O}_{3}$ nanoparticles. Hepatocarcinoma SMMC-7721 cells cultured in vitro were treated with ferrofluid containing $\mathrm{Fe}_{2} \mathrm{O}_{3}$ nanoparticles and irradiated with an alternating radio frequency magnetic field. The influence of the treatment on the cells was examined by inverted microscopy, MTT and flow cytometry. To study the therapeutic mechanism of the $\mathrm{Fe}_{2} \mathrm{O}_{3} \mathrm{MFH}, \mathrm{Hsp} 70, \mathrm{Bax}, \mathrm{Bcl}-2$ and p53 were detected by immunocytochemistry and reverse transcription polymerase chain reaction (RT-PCR). It was shown that $\mathrm{Fe}_{2} \mathrm{O}_{3} \mathrm{MFH}$ could cause cellular necrosis, induce cellular apoptosis, and significantly inhibit cellular growth, all of which appeared to be dependent on the concentration of the $\mathrm{Fe}_{2} \mathrm{O}_{3} \mathrm{nanoparticles}$. Immunocytochemistry results showed that MFH could induce high expression of Hsp70 and Bax, decrease the expression of mutant p53, and had little effect on Bcl-2. RT-PCR indicated that Hsp70 expression was high in the early stage of MFH (<24 h) and became low or absent after $24 \mathrm{~h}$ of MFH treatment. It can be concluded that $\mathrm{Fe}_{2} \mathrm{O}_{3} \mathrm{MFH}$ significantly inhibited the proliferation of in vitro cultured liver cancer cells (SMMC-7721), induced cell apoptosis and arrested the cell cycle at the $\mathrm{G}_{2} / \mathrm{M}$ phase. $\mathrm{Fe}_{2} \mathrm{O}_{3} \mathrm{MFH}$ can induce high $\mathrm{Hsp} 70$ expression at an early stage, enhance the expression of Bax, and decrease the expression of mutant p53, which promotes the apoptosis of tumor cells.
\end{abstract}

Key words: $\mathrm{Fe}_{2} \mathrm{O}_{3}$; Magnetic nanoparticles; Magnetic fluid hyperthermia; Hepatocarcinoma cells; Liver cancer

\section{Introduction}

In 1997, Jordan et al. (1) first reported a novel method of using magnetic fluid hyperthermia (MFH), which is carried out through the combination of nanotechnology and magnetic induction hyperthermia, to treat tumors, and remarkable results were obtained. This therapy is also known as targeted intracellular hyperthermia. Yanase et al. (2) and Shinkai et al. (3) subsequently wrapped the magnetic nanoparticles in lipid membranes to generate magnetic liposomes (MLs) as intracellular hyperthermia agents with increased efficacy. It was found in later studies (4) that intracellular hyperthermia could also trigger immune responses.

One of the therapeutic mechanisms of MFH in killing tumor cells is the induction of cellular apoptosis $(5,6)$. Apoptosis is a physiological orderly cell death with a very complex mechanism that is subject to a variety of promoting and inhibiting factors. A variety of oncogenes and tumor suppressor genes have been demonstrated to regulate apoptosis, such as p53, Bcl-2, c-Myc, and transforming growth factor (TGF)- $\beta(7,8)$. The $\mathrm{Bcl}-2$ family has received extensive attention, since it appears to be the common destination of various apoptosis pathways and thus regulates apoptosis. These genes play important roles not only in the formation and development of tumors but also in tumor therapies. Regulation of apoptosis by the $\mathrm{Bcl}-2$ and $\mathrm{Bax}$ genes, both of which are members of the $\mathrm{Bcl}-2$ family, has increasingly become a research topic in molecular biology. $\mathrm{Bcl}-2$ is antiapoptotic and its overexpression (Bcl-2$\mathrm{Bcl}-2)$ results in apoptosis inhibition and cell survival, whereas Bax is proapoptotic $(9,10)$, and its overexpression (Bax-Bax) leads to cell death. However, the expression of the apoptosis suppressor gene $\mathrm{Bcl}-2$ is low or nonexistent in

Correspondence: L.M. Xu and/or Y. Hu, Department of Gastroenterology, Xinhua Hospital, Shanghai Jiaotong University School of Medicine, Shanghai 200092, China. Fax: +86-021-6029-9411. E-mail: leiming.xu@aliyun.com.cn and/or huying@sohu.com 
hepatoma cells $(11,12)$, whereas Bax is widely distributed in various organs including normal liver tissues, which indicates that Bax is probably an important apoptosisregulating gene (13). Bai et al. (14) reported the abnormal expression of Bax in Hodgkin's disease. Bcl-2 and Bax have been shown to have an important influence in regulating the apoptosis of gastric cancer, prostate cancer, ovarian cancer, and other tumor cells (15). However, correlation of the apoptosis index with $\mathrm{Bcl}-2$, Bax, and related proteins in hepatocellular carcinoma has not been reported (16). In addition, the $p 53$ gene not only regulates cell proliferation and differentiation but also participates in regulating apoptosis. The wild-type $p 53$ gene promotes apoptosis, whereas the mutant $p 53$ gene inhibits apoptosis (17). The mutant $p 53$ can downregulate the expression of $\mathrm{Bcl}-2$ (18). Guo et al. (19) reported no significant relationship between Bax and p53. The abnormal expression of Bax and p53 in hepatocellular carcinoma indicates that the two proteins may be associated with liver cancer but have different mechanistic pathways.

In this study, hepatocarcinoma cells were treated in vitro with ferrofluids containing various concentrations of $\mathrm{Fe}_{2} \mathrm{O}_{3}$ nanoparticles and irradiated with an alternating magnetic field. The influence of the treatment on the cells was examined by inverted microscopy, transmission electron microscopy (TEM), methylthiazoletetrazolium (MTT) viability assay and flow cytometry. To further evaluate the therapeutic mechanism of the treatment, Hsp70, Bax, Bcl-2 and p53 were detected by immunocytochemistry (IC) and reverse transcription polymerase chain reaction (RT-PCR). The experimental results are expected to establish a reliable basis for the clinical treatment of liver cancer.

\section{Material and Methods}

\section{Reagents and equipment}

SMMC-7721 human hepatoma cells were purchased from the Shanghai Institute of Biology and Cell Biochemistry, Chinese Academy of Science. RPMI 1640 culture medium was purchased from Gibco-BRL (USA). Trypsin $(0.25 \%)$ was purchased from AMRESCO (USA). MTT and diethyl bicarbonate (DEPC) were purchased from Sigma (USA). Giemsa dye was purchased from Chroma (USA). AMV reverse transcriptase, dNTP, Oligo(dT)18, Taq DNA polymerase, 100 bp DNA ladder, RNasin (40 U/L), and RNase-free DNase I were all purchased from Takara Co. (China). The immunocytochemical reagents, streptavidinperoxidase (SP) staining kit and liquid aminoethyl carbazole (AEC) enzyme substrate visualization kit were purchased from Beijing Zhongshan Biotechnology Co., Ltd., China. All biochemical reagents used in this study were of analytical grade.

A PTC-100 thermal cycler, Multiskan MK3-353 enzyme linked immunosorbent assay (ELISA) reader and Vantage SE fluorescence-activated cell sorting (FACS) system (USA) were used. An inverted microscope and JEM-2010 high-resolution transmission electron microscope (JEOL, Japan) were used. An SP-04C high-frequency induction heater (Shenzhen Shuangping High-Frequency Heater Factory, China) was used with the following operating parameters: frequency $=200 \mathrm{kHz}$; power $=4 \mathrm{~kW}$; output alternating heating current $=100-350 \mathrm{~A}$.

\section{Experiment}

The experiment was divided into 4 groups. The blank group contained the RPMI 1640 culture medium only (control group A), while a second control group with the same composition received magnetic irradiation (control group $\mathrm{B}$ ). The third group contained $8 \mathrm{~g} / \mathrm{L} \mathrm{Fe} \mathrm{O}_{3}$ nanoparticle ferrofluid in RPMI 1640 medium but was not heated (spiking group). The final group contained various concentrations of $\mathrm{Fe}_{2} \mathrm{O}_{3}$ nanoparticle ferrofluid $(2,4,6$, $8 \mathrm{~g} / \mathrm{L}$ ) in RPMI 1640 and was heated by magnetic irradiation (MFH group). The $\mathrm{Fe}_{2} \mathrm{O}_{3}$ nanoparticle ferrofluid was prepared using sterile RPMI 1640 medium. SMMC7721 cells in the logarithmic proliferation phase were used in the experiments. MFH heating was carried out by placing the sample on the coil plate of the SP-04C high frequency heater and applying a high frequency alternating current (AC) alternating magnetic field $(200 \mathrm{kHz}, 4 \mathrm{~kW}$, output current $300 \mathrm{~A})$.

\section{Preparation and characterization of $\mathrm{Fe}_{2} \mathrm{O}_{3}$ magnetic nanoparticles}

The magnetic nanoparticles used in the present study were made of maghemite $\left(\gamma-\mathrm{Fe}_{2} \mathrm{O}_{3}\right)$, which was synthesized according to the following procedures: 1) $\mathrm{Fe}_{3} \mathrm{O}_{4}$ nanoparticles were prepared. Briefly, a combined solution of $\mathrm{FeCl}_{3}(1 \mathrm{~mol} / 25 \mathrm{~mL}$ water $)$ and $\mathrm{FeSO}_{4} .7 \mathrm{H}_{2} \mathrm{O}(0.6 \mathrm{~mol} /$ $25 \mathrm{~mL}$ water) was stirred under nitrogen followed by the rapid addition of $15 \mathrm{~mL}$ ammonia (25\%) and further stirring for $15 \mathrm{~min}$. The dark precipitate of magnetite particles $\left(\mathrm{Fe}_{3} \mathrm{O}_{4}\right)$ that formed was isolated using a permanent magnet and dried under vacuum. 2) $\gamma-\mathrm{Fe}_{2} \mathrm{O}_{3}$ nanoparticles were prepared as follows. The $\mathrm{Fe}_{3} \mathrm{O}_{4}$ nanoparticles were suspended in solution of $\mathrm{Fe}\left(\mathrm{NO}_{3}\right)$ at a concentration of $5 \mathrm{~g} / \mathrm{L}$. The particles were oxidized into maghemite at $90^{\circ} \mathrm{C}$ with $\mathrm{O}_{2}$ for $30 \mathrm{~min}$. When the dark precipitate became brown, the $\gamma-\mathrm{Fe}_{2} \mathrm{O}_{3}$ nanoparticles were isolated with a permanent magnet. The nanoparticle diameters (ranging from 10 to $20 \mathrm{~nm}$ ) were controlled by varying the proportion of iron (II) and iron (III), as previously described (20).

\section{Microscopic observation of cell morphology}

Cells were added to the culture medium $(5 \mathrm{~mL})$ corresponding to each experimental group. Each sample of the MFH group received $1 \mathrm{~h}$ irradiation. All samples were then further cultured for $48 \mathrm{~h}$ at $37^{\circ} \mathrm{C}$ in an incubator with $5 \% \mathrm{CO}_{2}$, and saturated humidity. Cell morphology was observed and photographed using an inverted optical microscope and TEM. 


\section{Cell proliferation rate measured by MTT}

The SMMC- 7721 cells were digested with $0.25 \%$ trypsin and prepared as a cell suspension. The cell concentration was adjusted to $6 \times 10^{4} / \mathrm{mL}$ and $100 \mu \mathrm{L}$ suspension $\left(6 \times 10^{3}\right.$ cells) was added to each well of a 96-well culture plate. Each group was assigned 8 wells, and $24 \mathrm{~h}$ after cell seeding, $100 \mu \mathrm{L}$ of the corresponding medium was added. The control group B and the MFH group were irradiated for $1 \mathrm{~h}$. After culturing for $48 \mathrm{~h}$, MTT (20 $\mu \mathrm{L}$ per well) was added. The mixtures were further cultured for $4 \mathrm{~h}$ and the liquids were discarded. To each well $160 \mu \mathrm{L}$ dimethylsulfoxide (DMSO) was added, the plate was shaken for $10 \mathrm{~min}$, centrifuged at $2500 \mathrm{~g}$ for $10 \mathrm{~min}$, and the supernatant liquids were transferred to the wells in another 96-well plate. The absorbance $(\mathrm{A})$ at $493 \mathrm{~nm}$ was measured using an automatic ELISA reader. The inhibition rate $(\%)=(1-$ $\left.A_{\text {experimental group }} / A_{\text {control group }}\right) \times 100$ and the proliferation rate $(\%)=\left(A_{\text {experimental group }} / A_{\text {control group }}\right) \times 100$.

\section{Flow cytometry analysis}

SMMC-7721 cells $\left(3 \times 10^{5} / \mathrm{mL}\right)$ were inoculated into $50 \mathrm{~mL}$ flasks (2 mL per flask) and cultured for $24 \mathrm{~h}$. A $3 \mathrm{~mL}$ volume of culture medium from control group $A$, the spiking group and the MFH group were added to individual flasks. The MFH group was irradiated for $1 \mathrm{~h}$ while the other two groups were placed at room temperature $\left(26^{\circ} \mathrm{C}\right)$ for $1 \mathrm{~h}$, after which all groups continued in culture for $48 \mathrm{~h}$. The cells were collected, washed twice with phosphate buffered saline (PBS), then fixed with $70 \%$ ethanol at $4{ }^{\circ} \mathrm{C}$ for $>24 \mathrm{~h}$. Before flow cytometry, cells were washed twice with PBS, resuspended in $0.5 \mathrm{~mL}$ propidium iodide $(\mathrm{PI} ; 0.05 \mathrm{~g} / \mathrm{L} \mathrm{PI}$, $0.1 \mathrm{~g} / \mathrm{L}$ RNase A) for staining $30 \mathrm{~min}$ at $26^{\circ} \mathrm{C}$ in the dark. They were then passed through a 300 -mesh filter and analyzed with the flow cytometer. Data were analyzed using the Lysis II software (Becton-Dickinson, USA) software.

\section{TUNEL apoptosis assay}

DNA fragmentation was detected by terminal deoxynucleotidyl transferase dUTP nick end labeling (TUNEL) assay, using the DeadEnd ${ }^{\mathrm{TM}}$ Fluorometric TUNEL System (Promega Corporation, USA). Cells $\left(5 \times 10^{3}\right.$ per well) were plated onto 96-well flat bottom plates (Corning Inc., USA) and allowed to attach overnight prior to treatment. The assay was performed as previously described by Kristjansdottir (21). Experiments were performed in triplicate.

Immunocytochemistry detection of Hsp70, Bax, Bcl-2 and p53 expression

Cells seeding and handling. The SMMC-7721 cells $\left(3 \times 10^{5} / \mathrm{mL}\right)$ were inoculated into 6 -well plates where each well carried a coverslip. A volume of $2 \mathrm{~mL}$ cell suspension and $3 \mathrm{~mL}$ RPMI 1640 culture medium were added to each well. The mixtures were cultured for $24 \mathrm{~h}$ until the cells attached to the coverslip and were then assigned to the control group A and the MFH group. The wells of the MFH group were irradiated for $1 \mathrm{~h}$. After further culturing for 24$48 \mathrm{~h}$, the coverslips were removed, washed twice with $\mathrm{pH}$ 7.2-7.4 PBS, air dried, fixed with cold acetone for 5-10 min, air dried (or blow dried), fixed onto $26 \times 76 \mathrm{~mm}^{2}$ slides using neutral gum, and stored at $-20^{\circ} \mathrm{C}$.

Immunocytochemical staining. The cell-seeded coverslips were washed twice with PBS and dried. An appropriate amount of $3 \% \mathrm{H}_{2} \mathrm{O}_{2}$ was added dropwise and the mixture was incubated for $10 \mathrm{~min}$ at $37^{\circ} \mathrm{C}$ in a $100 \%$ humidity incubator, washed with distilled water and soaked in PBS for 5 min. Normal goat serum blocking solution was added dropwise and the mixture was incubated at room temperature for $15 \mathrm{~min}$, then decanted (but not washed). From this point on, the dilute solution of mouse anti-human antibodies (Hsp70, Bax, bcl-2, p53) was added dropwise and the mixture was incubated at $37^{\circ} \mathrm{C}$ for $2 \mathrm{~h}$; then the biotinylated goat anti-mouse secondary antibody was added dropwise and the mixture was incubated at $37^{\circ} \mathrm{C}$ for $15 \mathrm{~min}$; and finally the working solution of horseradish peroxidase (HRP)-labeled streptavidin was added dropwise and the mixture was incubated at $37^{\circ} \mathrm{C}$ for $15 \mathrm{~min}$. Each incubation stage was followed by washing three times, 3 min each time, with PBS. Finally, freshly prepared AEC solution was added at room temperature and the mixture was examined under the microscope while staining for 10-30 min. The mixture was then extensively flushed with tap water for $10 \mathrm{~min}$ and restained with hematoxylin for 40-60 s. The appropriate timing was determined by microscopic observation. The re-staining step was omitted if observation indicated nuclear expression. The stained coverslip was sealed with ClearMount (Shanghai Sangge Biological Technology Co., Ltd., China) and heated at $70-80^{\circ} \mathrm{C}$ in an oven for $10-20 \mathrm{~min}$, then examined microscopically and photographed.

\section{RT-PCR detection of Hsp70 expression}

RNA concentration, purity and integrity. The SMMC7721 cells cultured in groups were extracted according to the Trizol manual and total RNA was purified. The RNA concentrations corresponding to the samples were calculated. RNA samples $(5 \mu \mathrm{L})$ were loaded in buffer solution and electrophoresed in $0.8 \%$ agarose denaturing gel. The presence of at least two full strips indicated that the RNA quality was sufficient to enable the reverse transcription experiment to continue.

Reverse transcription. The reverse transcription reaction system (total volume $20 \mu \mathrm{L}$ ) consisted of the RNA samples $(5 \mu \mathrm{L})$, Oligo $\mathrm{dT}_{18}(1 \mu \mathrm{L})$, dNTP $(10 \mathrm{mM}, 2 \mu \mathrm{L})$, RNasin $(0.5 \mu \mathrm{L})$, AMV $(1 \mu \mathrm{L}), 5 \times$ buffer $(4 \mu \mathrm{L})$, and DEPC water $(13.5 \mu \mathrm{L})$. The RNA sample was pre-denatured at $65^{\circ} \mathrm{C}$ for $10 \mathrm{~min}$ and placed in an ice bath for $10 \mathrm{~min}$ before its final addition to the reaction system. The reverse transcription then proceeded at $42^{\circ} \mathrm{C}$. The mixture was inactivated at $99^{\circ} \mathrm{C}$ for $5 \mathrm{~min}$ and then stored at $-20^{\circ} \mathrm{C}$.

$P C R$ amplification. 1) Primer customization and dilution: Hsp70 and $\beta$-actin primers were synthesized by 
Table 1. PCR reaction system

\begin{tabular}{lc}
\hline Material & Volume $(\mu \mathrm{L})$ \\
\hline $10 \times$ PCR buffer & 2 \\
dNTP & 0.5 \\
Hsp70 forward primer & 1 \\
Hsp70 reverse primer & 1 \\
$\beta$-actin forward primer & 1 \\
$\beta$-actin reverse primer & 1 \\
cDNA & 4 \\
$\mathrm{TaqE}$ & 0.5 \\
$\mathrm{MgCl}_{2}$ & 2 \\
\hline
\end{tabular}

Shenneng Bocai Biotechnology Co., Ltd (China) as previously described (22). The primers were diluted to $20 \mathrm{pmol} / \mu \mathrm{L}$, divided into aliquots and stored at $-70^{\circ} \mathrm{C}$ until use. 2) PCR reaction system (Table 1): the reaction system was diluted with DEPC water to $25 \mu \mathrm{L}$. cDNA was first denatured at $94^{\circ} \mathrm{C}$ for $2.5 \mathrm{~min}$ and then added to the reaction system. Amplification was carried out on the PTC-100 cycler (MJ Research Watertown Inc., USA). The amplification cycle for $\mathrm{Hsp} 70$ included denaturation at $94^{\circ} \mathrm{C}$ for $30 \mathrm{~s}$, annealing at $59^{\circ} \mathrm{C}$ for $30 \mathrm{~s}$ and extension at $72^{\circ} \mathrm{C}$ for $45 \mathrm{~s}$, for a total of 25 cycles; and then extension at $72^{\circ} \mathrm{C}$ for $10 \mathrm{~min}$ and storage at $-20^{\circ} \mathrm{C}$. The PCR conditions for $\beta$-actin were identical to those of Hsp70, except for annealing at $64^{\circ} \mathrm{C}$ and a total of 24 cycles. In the control experiment, distilled water was used as a negative control instead of cDNA in the PCR reaction system. Untreated MCF-7 cells that expressed Hsp70 were used as a positive control. Each DNA amplification was performed in the presence of positive and negative controls to ensure the reliability of the results. 3) Agarose gel electrophoresis: agarose $(0.5 \mathrm{~g})$ was added to $0.5 \times$ Tris-borate-EDTA (TBE) buffer $(25 \mathrm{~mL})$ to prepare $2.0 \%$ agarose gel. TBE was added to adjust the final concentration to $0.5 \mu \mathrm{g} / \mathrm{mL}$. When the temperature of the gel solution was approximately $50^{\circ} \mathrm{C}$, the gel was poured while avoiding air bubbles and the comb was inserted. After solidification, the gel was placed in the electrophoresis tank. Samples were spotted (5 $\mu \mathrm{L}$ PCR product, $1 \mu \mathrm{L}$ loading buffer) and electrophoresed in $0.5 \times$ TBE buffer at $80 \mathrm{~V}$. After $30 \mathrm{~min}$, the electrophoresis products were examined under UV light, scanned and photographed.

\section{Statistical analysis}

Data are reported as means $\pm S D$. The Poisson distribution was used to evaluate differences between the control group and treatment groups. ANOVA was performed between treatment groups. All statistical analyses were performed using SAS 8.1 and SPSS version 10.0.

\section{Results}

\section{Cell morphological changes}

It was observed under the inverted microscope that the cells of control group A exhibited uniform size with no cell rupture or fragmentation. The cells were abundant and attached well. The spiking group was essentially the same as control group A except that some magnetic material had entered into or deposited among the cells. The cells of the MFH group showed notable changes in morphology. The temperature increase was positively correlated with the concentration of the $\mathrm{Fe}_{2} \mathrm{O}_{3}$ nanoparticle ferrofluid $(2 \mathrm{~g} / \mathrm{L} \rightarrow$ $\left.39^{\circ} \mathrm{C}, 4 \mathrm{~g} / \mathrm{L} \rightarrow 41^{\circ} \mathrm{C}, 6 \mathrm{~g} / \mathrm{L} \rightarrow 43^{\circ} \mathrm{C}, 8 \mathrm{~g} / \mathrm{L} \rightarrow 47^{\circ} \mathrm{C}\right)$. The number of normal cells gradually decreased whereas necrotic cells and cell debris became abundant. Cell attachment was poor or absent. The magnetic material was increasingly deposited, and in some cases the cells were not visible (Figure 1).

Electron microscopy results showed that the control
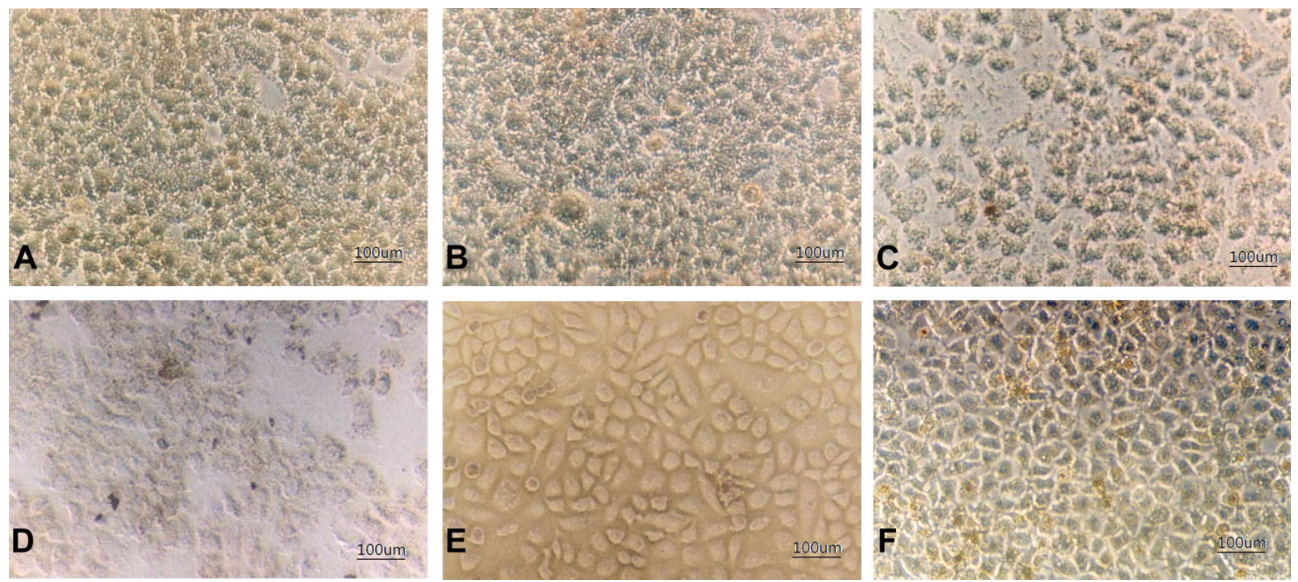

Figure 1. Morphology of SMMC-7721 cells under inverted microscope $(100 \times)$. A, $2 \mathrm{~g} / \mathrm{L} \mathrm{Fe} \mathrm{O}_{3} \mathrm{MFH}$ group; $B, 4 \mathrm{~g} / \mathrm{L} \mathrm{Fe} \mathrm{O}_{3} \mathrm{MFH}$ group; $C, 6 \mathrm{~g} / \mathrm{L} \mathrm{Fe} \mathrm{O}_{3} \mathrm{MFH}$ group; $D, 8 \mathrm{~g} / \mathrm{L} \mathrm{Fe} \mathrm{O}_{3} \mathrm{MFH}$ group; $E, 8 \mathrm{~g} / \mathrm{L} \mathrm{Fe} \mathrm{O}_{3}$ spiking group (no radiation); $F$, control group $\mathrm{A}$ (RPMI 1640 culture medium only). MFH: magnetic fluid hyperthermia. 


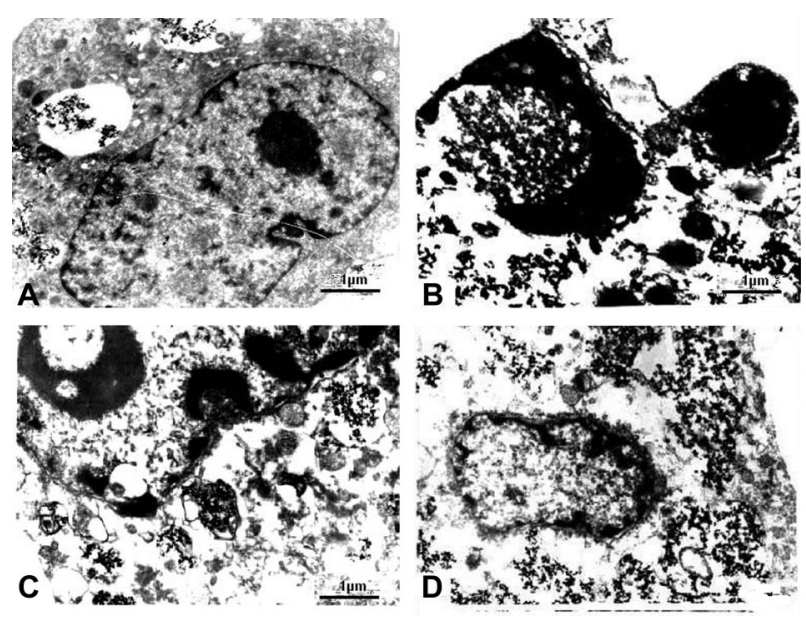

Figure 2. Morphology of SMMC-7721 cells after treatment. $A$, spiking group (8 $\mathrm{g} / \mathrm{L} \mathrm{Fe}_{2} \mathrm{O}_{3}$, no radiation); $B-D$, MFH groups $(4,6$ and $8 \mathrm{~g} / \mathrm{L} \mathrm{Fe}_{2} \mathrm{O}_{3}$, respectively). MFH: magnetic fluid hyperthermia.

group A had normal cell morphology. The cells of the spiking group also appeared normal with nanomaterials visibly deposited inside and outside the cells. The hepatoma cells of the MFH group exhibited chromatin condensation, cytoplasmic vacuolization, and formation of apoptotic bodies. Nanomaterials were visibly deposited in the nucleus, cytoplasm and lysosomes (Figure 2), and were confirmed to be $\mathrm{Fe}_{2} \mathrm{O}_{3}$ nanoparticles by spectral analysis (Figure 3).

\section{MTT experimental results (Table 2)}

The viability of each group was calculated from the measured absorbance $(A)$ values as cell survival rate (\%) $=\left(A_{\text {average, experimental group }} / A_{\text {average, control group }}\right) \times 100$. The results of the MTT assay are shown in Figure 4. MFH using $\mathrm{Fe}_{2} \mathrm{O}_{3}$ nanoparticles significantly inhibited the proliferation of SMMC-7721 cells. The inhibition rate was clearly dependent on the ferrofluid concentration, and the maximum inhibition rate reached $81.77 \%$. A significant difference $(P<0.05)$ was noted between the MFH group and all other groups (control group A, control group $B$, and spiking group) (Figure 4).

\section{Flow cytometry}

The flow cytometry results showed that in the MFH group after $48 \mathrm{~h}$, obvious hypodiploid DNA (apoptotic) peaks appeared before the $\mathrm{G} 1$ peak, and the apoptosis rate increased with rising concentration of the $\mathrm{Fe}_{2} \mathrm{O}_{3}$ nanoparticle ferrofluid. The cell cycles were arrested at the $\mathrm{G} 2 / \mathrm{M}$ phase to various degrees. The control group and the spike group showed no obvious apoptosis peaks (Figure 5).

\section{TUNEL assay results}

The TUNEL assay results revealed many apoptotic cells

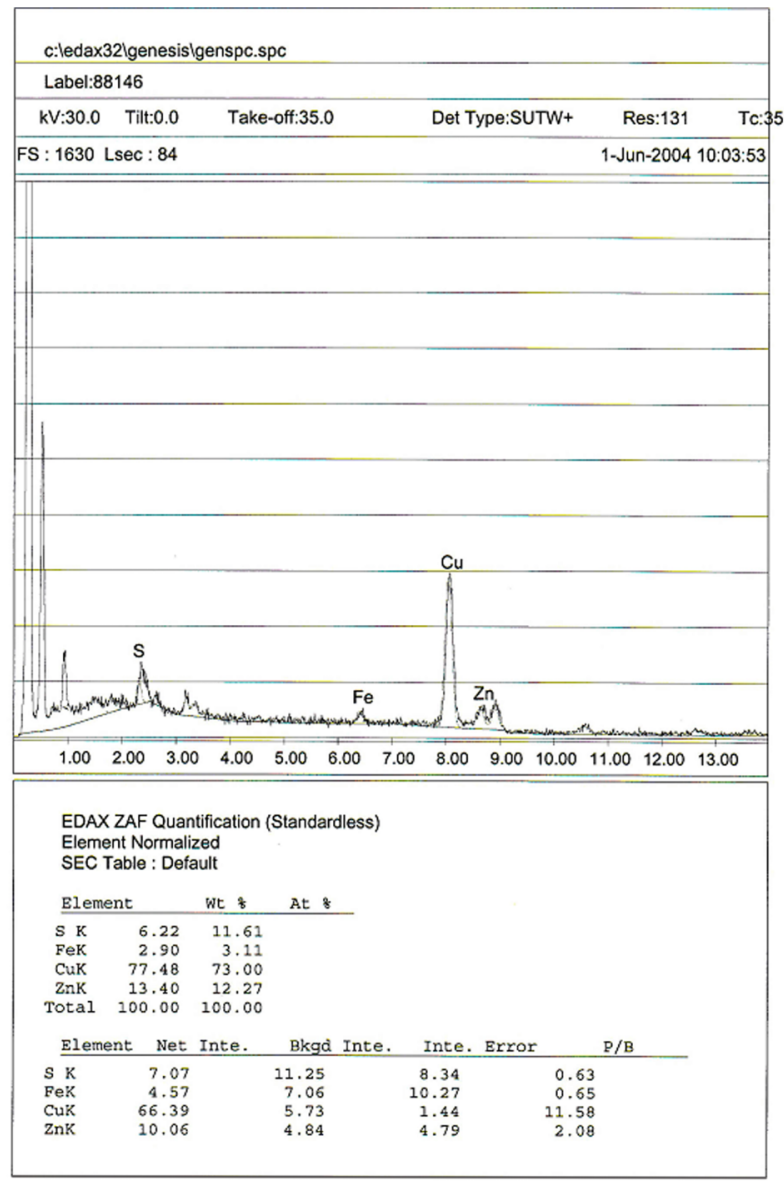

Figure 3. Energy spectrum of intracellular magnetic nanoparticle deposits in SMMC-7721 cells.

in the MFH groups. The apoptosis rate increased with rising concentration of the $\mathrm{Fe}_{2} \mathrm{O}_{3}$ nanoparticle ferrofluid. However, fewer, or no, apoptotic cells were found in the $\mathrm{Fe}_{2} \mathrm{O}_{3}$ nanoparticle group and the simple magnetic radiation group. Compared with the control group and the spiking group, the MFH groups showed significant differences in apoptotic cells rate. The proportion of apoptotic cells was significantly increased with increased $\mathrm{Fe}_{2} \mathrm{O}_{3}$ nanoparticle concentrations in the MFH groups (Figures 6 and 7).

\section{Immunocytochemical test results}

Staining criteria. Hsp70 positive sites were concentrated in the cell membrane and cytoplasm as rings or patches of red or reddish-brown color. The nuclei were negative. Bax and $\mathrm{Bcl}-2$ staining was mainly in the cytoplasm appearing as red or reddish-brown patches. p53 staining was mainly in the nucleus appearing as uniform red or red-brown particles. The morphology of the entire nucleus was clearly visible.

The cells adhering to a coverslip were deemed positive if the percentage of positive cells accounted for $>10 \%$ of the tumor cells examined in 10 high-power fields 
Table 2. MTT results of SMMC-7721 cells after MFH using $\mathrm{Fe}_{2} \mathrm{O}_{3}$ nanoparticles.

\begin{tabular}{lccc}
\hline Groups & ABS value & Cell survival rate (\%) & Toxicity classification \\
\hline Control group A & $0.384 \pm 0.027$ & 100.00 & 0 \\
Control group B & $0.383 \pm 0.026$ & 99.74 & 1 \\
Spiking group & $0.376 \pm 0.025$ & 97.91 & 1 \\
$\mathrm{MFH}$ group & & & \\
$2 \mathrm{~g} / \mathrm{L} \mathrm{Fe} \mathrm{O}_{3}$ & $0.270 \pm 0.037^{\mathrm{a}}$ & 70.31 & 2 \\
$4 \mathrm{~g} / \mathrm{L} \mathrm{Fe}_{2} \mathrm{O}_{3}$ & $0.266 \pm 0.050^{\mathrm{a}}$ & 69.27 & 2 \\
$6 \mathrm{~g} / \mathrm{L} \mathrm{Fe}_{2} \mathrm{O}_{3}$ & $0.170 \pm 0.040^{\mathrm{a}}$ & 44.27 & 3 \\
$8 \mathrm{~g} / \mathrm{L} \mathrm{Fe}_{2} \mathrm{O}_{3}$ & $0.070 \pm 0.014^{\mathrm{a}}$ & 18.23 & 4 \\
\hline
\end{tabular}

Data are reported as means \pm SD. Control group A: RPMI 1640 culture medium only; Control group B: RPMI 1640 culture medium and radiation; spiking group: $8 \mathrm{~g} / \mathrm{L} \mathrm{Fe}_{2} \mathrm{O}_{3}$, no radiation; $\mathrm{MFH}$ : magnetic fluid hyperthermia. ${ }^{\mathrm{a}} \mathrm{P}<0.05$ compared with control group $\mathrm{A}$, control group $\mathrm{B}$, and spiking group (t-test).

selected in different regions. A total of 200 clearly distributed tumor cells were counted by two observers in a double-blind manner and the mean was calculated. The positive index $(\mathrm{PI})$ values of each group were calculated as: $\mathrm{PI}=$ number of positive cells/number of total tumor cells $\times 100 \%$.

\section{Immunocytochemistry results for Hsp70}

The cells of the control group A and the spiking group were barely stained, if at all. In contrast, the membrane and cytoplasm of the MFH group cells were visibly red or reddish-brown (Figure 8). The $\mathrm{PI}$ of the $\mathrm{MFH}$ group increased with rising ferrofluid concentration, suggesting that hyperthermia induced Hsp70 expression.

\section{Immunocytochemistry results for p53}

For the control group and the spiking group, a large number of tumor cells were stained red in the nucleus due to p53 expression. The nuclear morphology was clearly

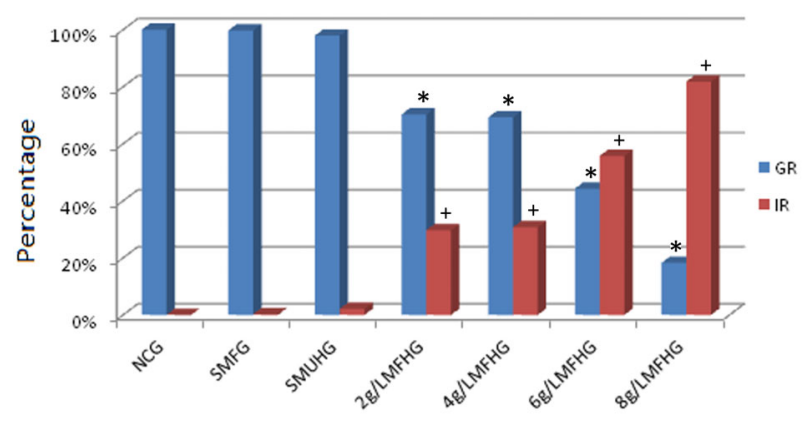

Figure 4. MTT histogram of SMMC-7721 cells after treatment. GR: growth rate; IR: inhibition rate; NCG: control group A (RPMI 1640 culture medium only); SMFG: control group B (RPMI 1640 culture medium and radiation); SMUHG: spiking group (8 g/L $\mathrm{Fe}_{2} \mathrm{O}_{3}$, no radiation); MFHG: magnetic fluid hyperthermia groups with $\mathrm{Fe}_{2} \mathrm{O}_{3}$ concentrations of $2,4,6$, and $8 \mathrm{~g} / \mathrm{L}$, respectively. ${ }^{*} \mathrm{P}<0.05$ compared with NCG growth rate; ${ }^{+} \mathrm{P}<0.05$ compared with NCG inhibition rate ( $t$-test). visible and the color was light. For the MFH group, particulate red or reddish-brown staining areas could be observed in the nucleus of the tumor cells. The number of positively stained cells and the staining intensity were negatively correlated with the ferrofluid concentration (Figure 9). The deposition of brown magnetic nanoparticles could be noted in intracellular and intercellular zones (Figure 10).

\section{Immunocytochemistry results for $\mathrm{Bax}$ and $\mathrm{Bcl}-2$}

In the control group A, Bax and Bcl-2 had different levels of expression. Specifically, particulate red-stained areas were visible in the cytoplasm whereas no obvious staining reaction was observed in the nucleus. The spiking group was largely identical to the control group A. In the MFH group, increasing the ferrofluid concentration significantly enhanced Bax expression while Bcl-2 expression changed little, and the staining was relatively light. Deposition of brownish magnetic nanoparticles could be noted both inside and outside the tumor cells (Figures 11 and 12). The ratio of Bax/Bcl-2 appeared to increase with rising ferrofluid concentration.

\section{RT-PCR results for Hsp70}

RNA concentration and purity. The $A_{260}$ and $A_{280}$ values of the RNA samples were measured and the ratios for all samples were found to be greater than 1.8, which met the requirement for RNA extraction. The presence of three complete strips (5S, 18S, 28S) following electrophoresis confirmed the RNA integrity (Figure 13).

\section{Electrophoresis}

After hyperthermia treatment for 8-12 h, electrophoresis results showed that $\mathrm{Hsp} 70$ and $\beta$-actin strips were not observed in control group $A$, the cells of the spiking group did not express Hsp70 but did express $\beta$-actin, and the target fragment was 240 bp in size. For control group B, target fragments appeared at 240 and $348 \mathrm{bp}$, corresponding to $\beta$-actin and $\mathrm{Hsp} 70$, respectively. The electrophoresis 

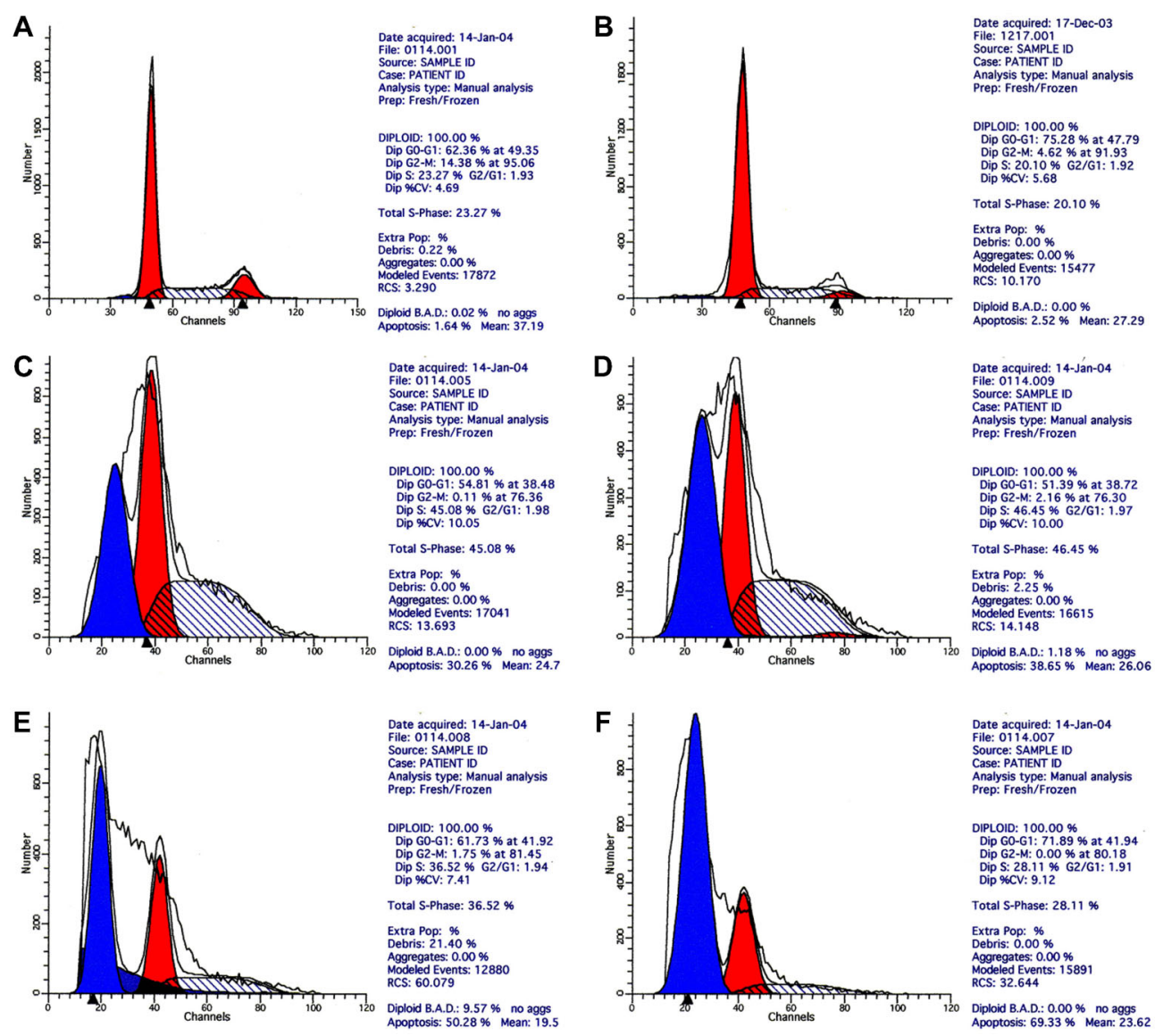

Figure 5. Flow cytometry of SMMC-7721 cells after treatment. $A$, Control group $\mathrm{A}$ (RPMI 1640 culture medium only); $B$, spiking group (8 g/L Fe $\mathrm{O}_{3}$, no radiation); $C, 2 \mathrm{~g} / \mathrm{L} \mathrm{Fe} \mathrm{O}_{3} \mathrm{MFH}$ group; $D, 4 \mathrm{~g} / \mathrm{L} \mathrm{Fe} \mathrm{O}_{3} \mathrm{MFH}$ group; $E, 6 \mathrm{~g} / \mathrm{L} \mathrm{Fe}_{2} \mathrm{O}_{3} \mathrm{MFH}$ group; $F, 8 \mathrm{~g} / \mathrm{L} \mathrm{Fe} 2 \mathrm{O}_{3} \mathrm{MFH}$ group. MFH: magnetic fluid hyperthermia.
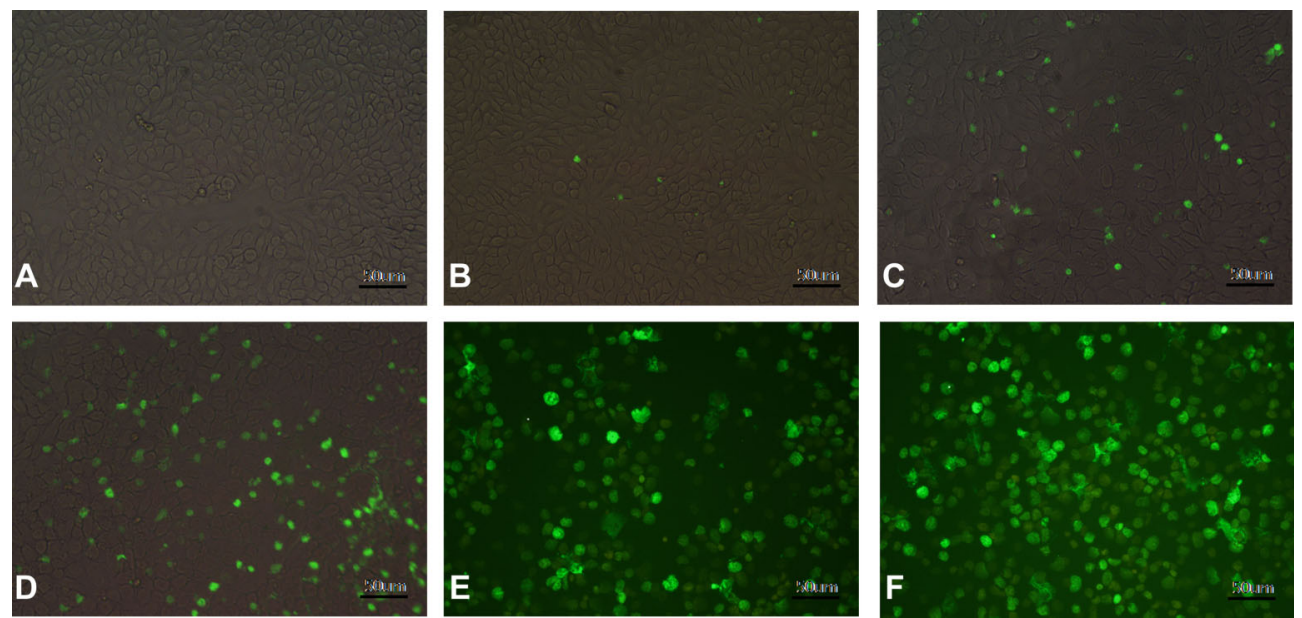

Figure 6. Apoptosis of SMMC-7721 cells $(200 \times)$ after treatment. $A$, Control group (RPMI 1640 culture medium only); $B$, spiking group (8 g/L Fe $\mathrm{O}_{3}$, no radiation); $C, 2 \mathrm{~g} / \mathrm{L} \mathrm{Fe} \mathrm{O}_{3} \mathrm{MFH}$ group; $D, 4 \mathrm{~g} / \mathrm{L} \mathrm{Fe} \mathrm{O}_{3} \mathrm{MFH}$ group; $E, 6 \mathrm{~g} / \mathrm{L} \mathrm{Fe} \mathrm{O}_{3} \mathrm{MFH}_{\text {group; }} F, 8 \mathrm{~g} / \mathrm{L} \mathrm{Fe} \mathrm{O}_{3} \mathrm{MFH}$ group. MFH: magnetic fluid hyperthermia. 


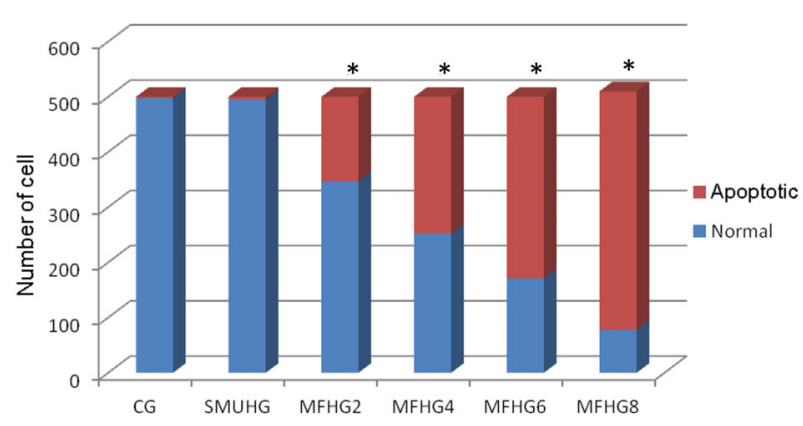

Figure 7. Apoptosis rates of treatment groups. CG: control group, SMUHG: spiking group (8 g/L $\mathrm{Fe}_{2} \mathrm{O}_{3}$, no radiation), MFHG: magnetic fluid hyperthermia groups with $2,4,6$, and $8 \mathrm{~g} / \mathrm{L} \mathrm{Fe}_{2} \mathrm{O}_{3}$. ${ }^{*} \mathrm{P}<0.05$ compared with control and spiking group (t-test).

images of the MFH group showed both $\beta$-actin and Hsp70 strips at 240 and $348 \mathrm{bp}$. The Hsp70 strip of the MFH group with $6 \mathrm{~g} / \mathrm{L} \mathrm{Fe}_{2} \mathrm{O}_{3}$ nanoparticle ferrofluid was the brightest (Figure 14A).

After hyperthermia treatment for $24 \mathrm{~h}$, there were no Hsp70 and $\beta$-actin strips in the control group A electrophoresis lane, the spiking group did not express Hsp70, but did express $\beta$-actin, and the target fragment was 240 bp in size. For the control group $\mathrm{B}$, target fragments appeared at 240 and $348 \mathrm{bp}$, corresponding to $\beta$-actin and Hsp70, respectively. The electrophoresis images of the MFH group were similar to those of the control group $A$ and the spiking group with no strip at $348 \mathrm{bp}$ (Figure 14B), indicating that after hyperthermia for $24 \mathrm{~h}$, the expressed proteins were degraded or Hsp70 expression was inhibited.

\section{Discussion}

\section{Effect of MFH on SMMC-7721 cells}

The tumor cells could load a significant amount of superparamagnetic $\mathrm{Fe}_{2} \mathrm{O}_{3}$ nanoparticles, and the daughter cells received $50 \%$ of the magnetic particles during cell division. Hence, not only the tumor cells but also their daughter cells were susceptible to the alternating magnetic field irradiation and both exhibited a high death rate (23). We found that $\mathrm{Fe}_{2} \mathrm{O}_{3}$ nanoparticles could enter into the cytoplasm and lysosomes of the SMMC-7721 cells. The $\mathrm{Fe}_{2} \mathrm{O}_{3}$ nanoparticles could efficiently convert the energy of the high-frequency alternating magnetic field $(200 \mathrm{kHz}$, $4 \mathrm{~kW}$, output current $300 \mathrm{~A}$ ) into heat. When the ferrofluid was diluted with $0.9 \% \mathrm{NaCl}$ to concentrations of $2,4,6$, or $8 \mathrm{~g} / \mathrm{L}$ and then heated for $60 \mathrm{~min}$ in high-frequency alternating magnetic field (output current $300 \mathrm{~A}$ ), the temperature rose to $39-54^{\circ} \mathrm{C}$. Note that after heating for $40 \mathrm{~min}$, the ferrofluid temperature no longer increased but remained at a constant level. Hence, the $\mathrm{Fe}_{2} \mathrm{O}_{3}$ nanoparticle ferrofluid can be a relatively noninvasive means to treat tumors with constant-temperature hyperthermia.

Electron microscopy, MTT assay and flow cytometry analysis showed that after MFH treatment, there were notable changes in the apoptotic SMMC-7721 cells, such as chromatin condensation, formation of crescent bodies, fragmentation of nuclei, and cell shrinkage. In addition, MFH induced SMMC-7721 cell apoptosis in a dosedependent manner, and the maximum apoptosis rate reached $69.33 \%$. Compared with control group cells, the MFH cells exhibited a notable hypodiploid peak ahead of
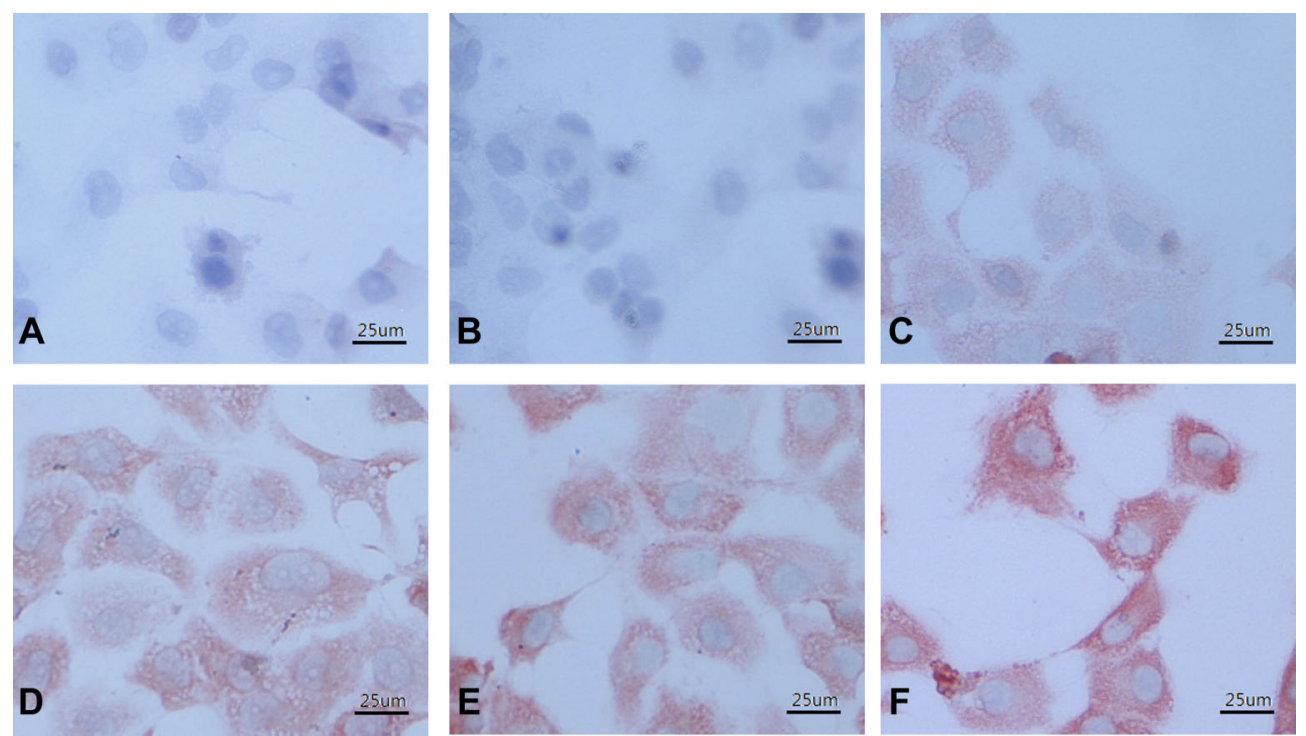

Figure 8. Immunochemical images $(400 \times)$ of Hsp70 expression in SMMC-7721 hepatoma cells. A, Control group A (RPMI 1640 culture medium only); $B$, spiking group (8 g/L Fe $\mathrm{O}_{3}$, no radiation), after $12 \mathrm{~h} ; C, 2 \mathrm{~g} / \mathrm{L} \mathrm{Fe} \mathrm{O}_{3} \mathrm{MFH}$ group, after $12 \mathrm{~h} ; D, 4 \mathrm{~g} / \mathrm{L} \mathrm{Fe} \mathrm{O}_{3}$ MFH group, after $12 \mathrm{~h} ; E, 6 \mathrm{~g} / \mathrm{L} \mathrm{Fe} \mathrm{F}_{3} \mathrm{MFH}$ group, after $12 \mathrm{~h} ; \mathrm{F}, 8 \mathrm{~g} / \mathrm{L} \mathrm{Fe} \mathrm{O}_{3} \mathrm{MFH}$ group, after $12 \mathrm{~h}$. MFH: magnetic fluid hyperthermia. 


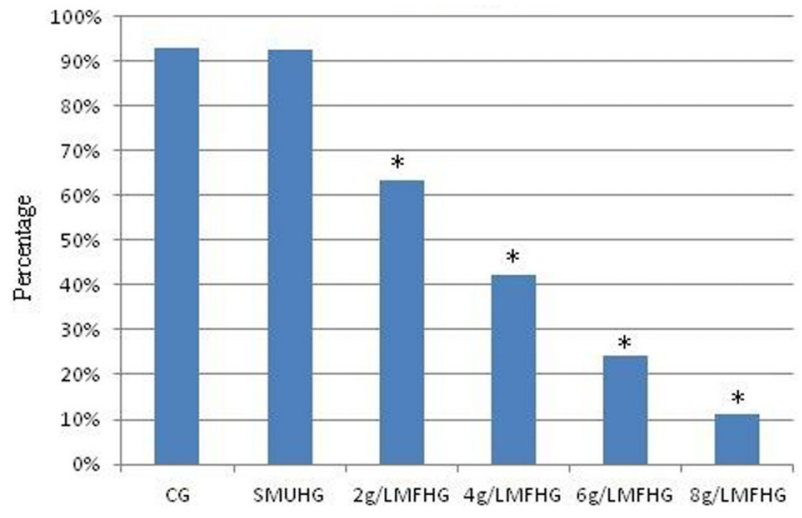

Figure 9. p53 histogram of SMMC-7721 cells after treatment. CG: control group A; SMUHG: spiking group (8 g/L $\mathrm{Fe}_{2} \mathrm{O}_{3}$, no radiation); MFHG: MFH group; $\mathrm{PI}$ : positive index. ${ }^{*} \mathrm{P}<0.05$ compared with CG (t-test).

the $\mathrm{G} 1$ peak. The cell cycle thus appeared to be arrested at the G2/M phase (24). Yuguchi also observed that hyperthermia could arrest the cell cycle at the G0/G1 phase (25). The MTT results showed that $\mathrm{Fe}_{2} \mathrm{O}_{3}$ nanoparticle ferrofluid hyperthermia inhibited the proliferation of SMMC-7721 cells. The inhibition rate increased with rising ferrofluid concentration and reached a maximum of $81.2 \%$.

\section{Effect of MFH on hepatocarcinoma-related genes and proteins}

Immunocytochemical staining showed that the tumor cells in the control group expressed Bax and Bcl-2 to various extents, as demonstrated by the particulate red staining zones in the cytoplasm; the nucleus showed no obvious coloration. The tumor cells of the spiking group appeared largely identical to those of the control group. In the MFH group, the Bax expression was enhanced remarkably with rising ferrofluid concentration, whereas the $\mathrm{Bcl}-2$ expression changed little and the staining reaction was relatively light. Deposition of brown nanoparticles was visible both inside and outside the tumor cells. In addition, the $\mathrm{Bax} / \mathrm{Bcl}-2$ ratio appeared to increase with rising ferrofluid concentration, suggesting that MFH could induce high Bax expression and exercise an antitumor effect by altering the $\mathrm{Bax} / \mathrm{Bcl}-2$ ratio. This is in agreement with Zhang (26) (24), who argued that Bcl-2 and Bax constitute a pair of positive and negative regulators. Their proteins are both homogeneous dimers, and during reaction one molecule of $\mathrm{Bcl}-2$ and one molecule of Bax are needed to combine into a heterodimer. The Bax/Bcl-2 ratio plays a key role in determining cell survival upon stimulation. Overexpression of $\mathrm{Bcl}-2$ (Bcl-2-Bcl-2) leads to cell survival whereas overexpression of Bax (Bax-Bax) causes cell death. Bian et al. (27) also reported that the expression of Bcl-2 in tumor cells decreased significantly after hyperthermia treatment whereas Bax expression was strongly enhanced. Tumor necrosis was not observed during cancer regression. Thus, it can be considered that hyperthermia can be used clinically to kill tumor cells through apoptosis.

It has also been reported that treating malignant fibrous histiocytoma MFH-2NR cells at $43^{\circ} \mathrm{C}$ for $1 \mathrm{~h}$ led to morphological changes indicative of apoptosis. The expression of Bax mRNA increased significantly and peaked after $30 \mathrm{~min}$ of heating, and the increased Bax expression was realized through the specific p53independent pathway (28). Immunocytochemistry studies showed that in the control group and the spiking group,
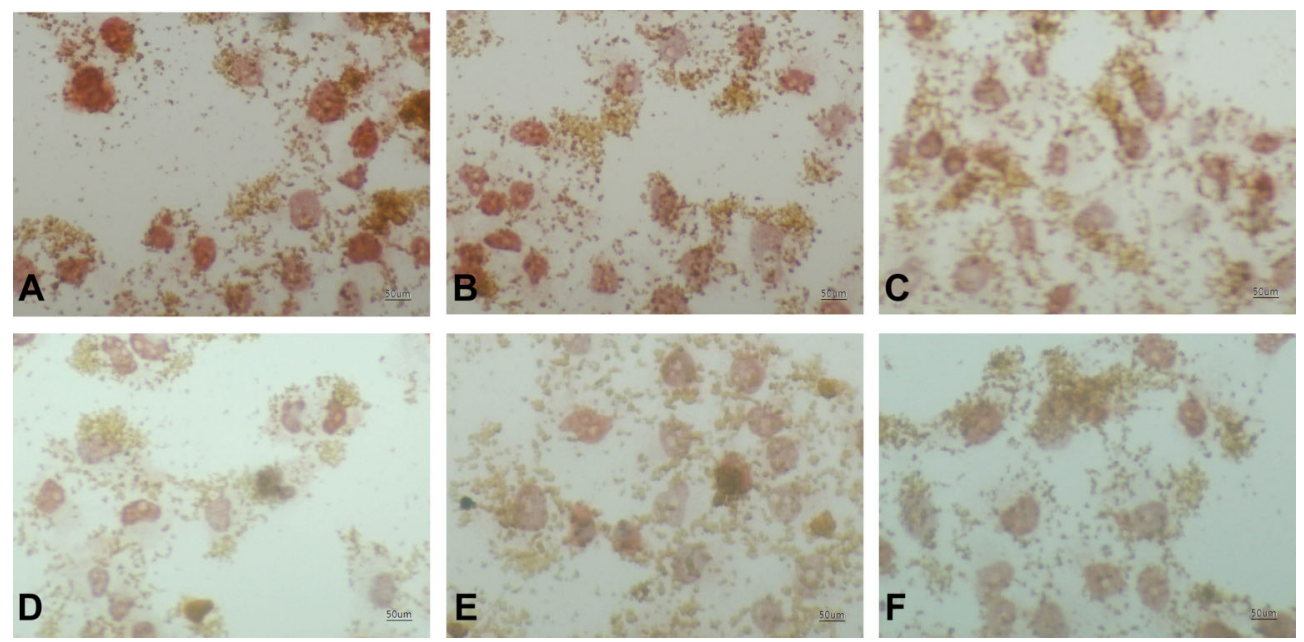

Figure 10. Immunocytochemical images $(200 \times)$ of p53 expression in SMMC-7721 hepatoma cells. A, Control group A (RPMI 1640 culture medium only); $B$, spiking group (8 g/L Fe $\mathrm{O}_{3}$, no radiation); $C, 2 \mathrm{~g} / \mathrm{L} \mathrm{Fe} \mathrm{O}_{3} \mathrm{MFH}$ group; $D, 4 \mathrm{~g} / \mathrm{L} \mathrm{Fe} \mathrm{O}_{3} \mathrm{MFH}$ group; $E$, $6 \mathrm{~g} / \mathrm{L}$ $\mathrm{Fe}_{2} \mathrm{O}_{3} \mathrm{MFH}$ group; $F, 8 \mathrm{~g} / \mathrm{L} \mathrm{Fe} \mathrm{O}_{3} \mathrm{MFH}$ group. MFH: magnetic fluid hyperthermia. 

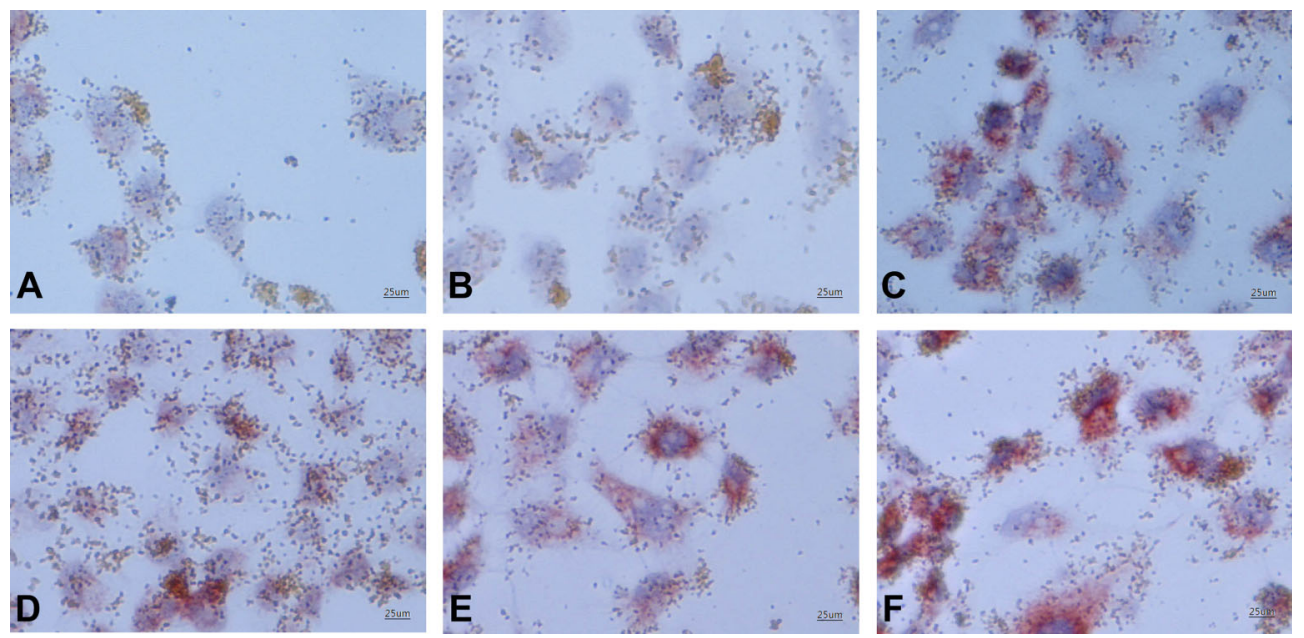

Figure 11. Immunocytochemical images $(400 \times)$ of Bax expression in SMMC-7721 hepatoma cells. A, Control group A (RPMI 1640 culture medium only); $B$, spiking group (8 g/L Fe $\mathrm{O}_{3}$, no radiation); $C, 2 \mathrm{~g} / \mathrm{L} \mathrm{Fe} \mathrm{O}_{3} \mathrm{MFH}$ group; $D, 4 \mathrm{~g} / \mathrm{L} \mathrm{Fe} \mathrm{O}_{3} \mathrm{MFH}$ group; $E, 6 \mathrm{~g} / \mathrm{L}$ $\mathrm{Fe}_{2} \mathrm{O}_{3} \mathrm{MFH}$ group; $F, 8 \mathrm{~g} / \mathrm{L} \mathrm{Fe}_{2} \mathrm{O}_{3} \mathrm{MFH}$ group. MFH: magnetic fluid hyperthermia.

the tumor cells nuclei readily expressed p53, which was stained red. The nucleus showed clear morphology with light staining color. In contrast, particulate red or reddishbrown stained areas could be seen in the nuclei of tumor cells in the MFH group. The number of positively stained cells and the staining intensity were negatively correlated with the ferrofluid concentration. The deposition of brown magnetic nanoparticles could be noted in intracellular and intercellular zones. Hyperthermia was found to increasingly inhibit mutant p53 expression with rising ferrofluid concentration. Low expression of mutant p53 resulted in relatively high expression of wild-type p53, which initiated a variety of proapoptotic pathways and promoted the antitumor effect. In addition, Matsumoto et al. (29) argued that heating can also stimulate the expression of wild-type p53 and suggested that hyperthermia-induced apoptosis is regulated by the p53 gene. Ohnishi et al. (30) suggested that P21/WAF1/CIP1 protein, which is the product of the oncogene $k$-ras, is an inhibitor of the cyclin D kinase (CDK) that can be activated by p53 at the transcription level to inhibit the progression of $\mathrm{G} 1 / \mathrm{S}$ phase cells and promote apoptosis. Heating can induce the expression of tumor necrosis factor (TNF)- $\alpha$ and promote apoptosis. Thus, hyperthermia mainly induces the expression of wild-type p53, inhibits the expression of mutant p53, increases the ratio of wild-type/mutant p53 proteins, and promotes the
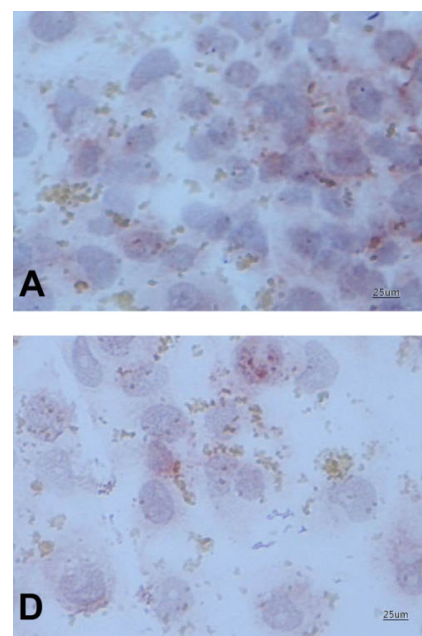
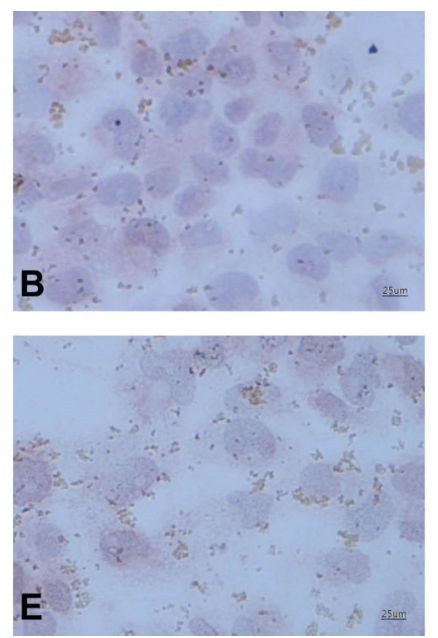
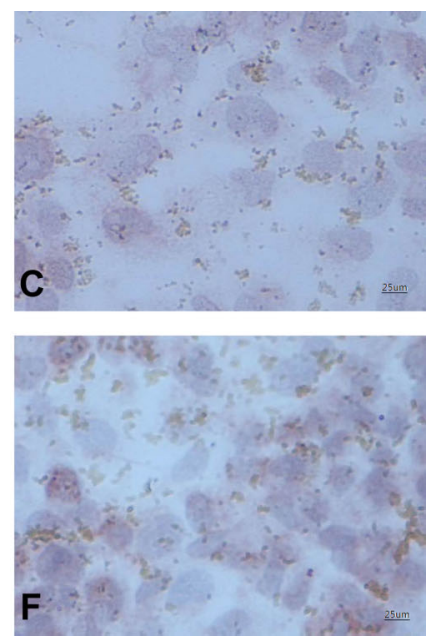

Figure 12. Immunocytochemical images $(400 \times)$ of $\mathrm{Bcl}-2$ expression in SMMC-7721 hepatoma cells. $A$, Control group $\mathrm{A}$ (RPMI 1640 culture medium only); $B$, spiking group ( $8 \mathrm{~g} / \mathrm{L} \mathrm{Fe}_{2} \mathrm{O}_{3}$, no radiation); $C, 2 \mathrm{~g} / \mathrm{L} \mathrm{Fe} \mathrm{O}_{3} \mathrm{MFH}$ group; $D, 4 \mathrm{~g} / \mathrm{L} \mathrm{Fe} \mathrm{O}_{3} \mathrm{MFH}$ group; $E, 6 \mathrm{~g} / \mathrm{L}$ $\mathrm{Fe}_{2} \mathrm{O}_{3} \mathrm{MFH}$ group; $F, 8 \mathrm{~g} / \mathrm{L} \mathrm{Fe} \mathrm{O}_{3} \mathrm{MFH}$ group. MFH: magnetic fluid hyperthermia. 


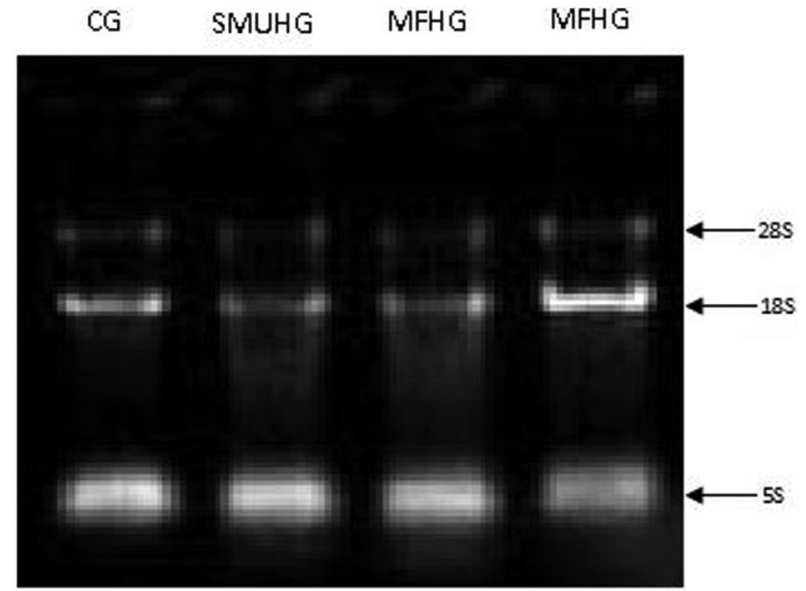

Figure 13. Results of RNA electrophoresis of SMMC-7721 cells in 3 groups. CG: control group A (RPMI 1640 culture medium only); SMUHG: spiking group (8 g/L $\mathrm{Fe}_{2} \mathrm{O}_{3}$, no radiation); MFHG: magnetic fluid hyperthermia group (lane 3: $2 \mathrm{~g} / \mathrm{L} \mathrm{Fe}_{2} \mathrm{O}_{3}$; lane 4: $8 \mathrm{~g} / \mathrm{L} \mathrm{Fe}_{2} \mathrm{O}_{3}$ ).

apoptosis of SMMC-7721 cells through a series of proapoptotic pathways.

The so-called thermal tolerance phenomenon can be experienced in hyperthermia, where more repetitions of treatment appear to deteriorate the efficacy. It has been suggested that the thermal tolerance of tumor cells is associated with the Hsp family $(31,32)$. The expression of Hsp70 protein and mRNA of SMMC-7721 cells after MFH treatment was examined by immunocytochemistry and RT-PCR. It was found that the expression of both Hsp70 protein and mRNA increased after $8 \mathrm{~h}$ and peaked after $12 \mathrm{~h}$ of MFH treatment, and no expression was observed after $24 \mathrm{~h}$. The results indicate that Hsp70 is relevant to the thermal tolerance in the early stage of the MFH treatment, but has little influence on the apoptosis.

Therefore, in this study, the therapeutic effect of $\mathrm{Fe}_{2} \mathrm{O}_{3}$ nanoparticle ferrofluid on SMMC-7721 cells in hyperthermia treatment was mainly due to increased Bax/ Bcl-2 ratio and increased wild-type/mutant p53 protein ratio, which promoted the apoptosis of hepatoma cells. Hsp70 has relatively little direct effect of tumor cell apoptosis in the hyperthermia treatment. Hsp70 may be responsible for the thermal tolerance observed in the early stage of hyperthermia and for part of the antitumor immunity.

\section{Acknowledgments}

Research supported by the National Natural Science Foundation of China (\#81071888, \#81070344, \#81070322, and \#81270491), the National Key Basic Research Project (\#2012CB517501), the 100-Talents Program of the Shanghai Municipal Health Bureau (\#XBR2011007) and the Cross Research Fund of Shanghai Jiaotong University Biomedical Engineering (\#YG2012MS37).
A
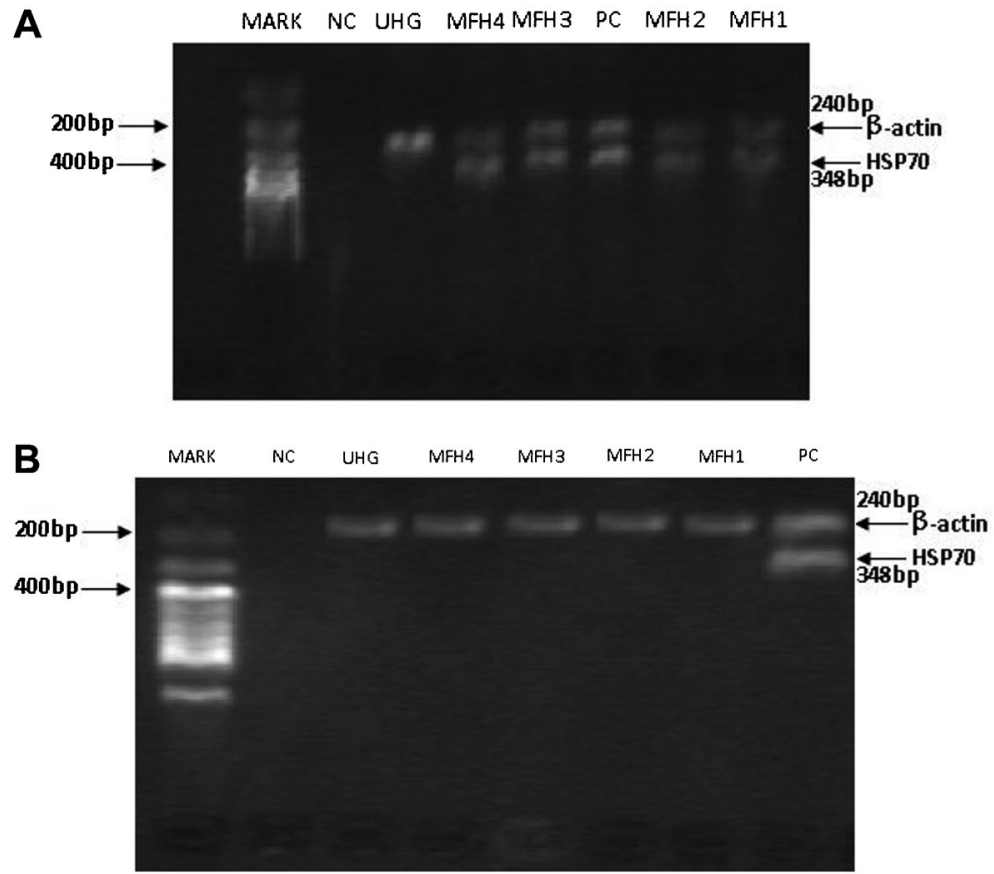

Figure 14. RT-PCR detection of Hsp70 expression for SMMC-7721 cells after treatment for $12 \mathrm{~h}$ $(A)$ and $24 \mathrm{~h}(B)$. NC: control group A (distilled water only); UHG: spiking group (8 g/L $\mathrm{Fe}_{2} \mathrm{O}_{3}$, no radiation); $\mathrm{MFH} 4$ : MHF group with $8 \mathrm{~g} / \mathrm{L}$ $\mathrm{Fe}_{2} \mathrm{O}_{3}$; MFH3: MHF group with $6 \mathrm{~g} / \mathrm{L} \mathrm{Fe}_{2} \mathrm{O}_{3} ; \mathrm{PC}$ : control group B (MCF-7 cell group only); $\mathrm{MFH} 2$ : MHF group with $4 \mathrm{~g} / \mathrm{L} \mathrm{Fe}_{2} \mathrm{O}_{3}$; MFH1: MHF group with $2 \mathrm{~g} / \mathrm{L} \mathrm{Fe}_{2} \mathrm{O}_{3}$. 


\section{References}

1. Jordan A, Scholz R, Wust P, Fahling H, Krause J, Wlodarczyk $\mathrm{W}$, et al. Effects of magnetic fluid hyperthermia (MFH) on $\mathrm{C} 3 \mathrm{H}$ mammary carcinoma in vivo. Int J Hyperthermia 1997; 13: 587-605, doi: 10.3109/02656739709023559.

2. Yanase M, Shinkai M, Honda H, Wakabayashi T, Yoshida J, Kobayashi T. Intracellular hyperthermia for cancer using magnetite cationic liposomes: an in vivo study. Jpn J Cancer Res 1998; 89: 463-469, doi: 10.1111/j.1349-7006.1998. tb00586.x

3. Shinkai M, Yanase M, Suzuki M, Honda H, Wakabayashi T, Yoshida J, et al. Intracellular hyperthermia for cancer using magnetite cationic liposomes. J Magn Magn Mater 1999; 194: 176-184, doi: 10.1016/S0304-8853(98)00586-1.

4. Frey B, Weiss EM, Rubner Y, Wunderlich R, Ott OJ, Sauer $\mathrm{R}$, et al. Old and new facts about hyperthermia-induced modulations of the immune system. Int $J$ Hyperthermia 2012; 28: 528-542, doi: 10.3109/02656736.2012.677933.

5. Wang DC, Zhang Y, Chen HY, Li XL, Qin LJ, Li YJ, et al. Hyperthermia promotes apoptosis and suppresses invasion in C6 rat glioma cells. Asian Pac J Cancer Prev 2012; 13: 3239-3245, doi: 10.7314/APJCP.2012.13.7.3239.

6. Zhou J, Wang X, Du L, Zhao L, Lei F, Ouyang W, et al. Effect of hyperthermia on the apoptosis and proliferation of CaSki cells. Mol Med Rep 2011; 4: 187-191.

7. Groeger AM, Esposito V, De Luca A, Cassandro R, Tonini $\mathrm{G}$, Ambrogi V, et al. Prognostic value of immunohistochemical expression of $\mathrm{p} 53$, bax, $\mathrm{Bcl}-2$ and $\mathrm{Bcl}-\mathrm{xL}$ in resected non-small-cell lung cancers. Histopathology 2004; 44: 5463, doi: 10.1111/j.1365-2559.2004.01750.x.

8. Bleicken S, Wagner C, Garcia-Saez AJ. Mechanistic differences in the membrane activity of Bax and Bcl-xL correlate with their opposing roles in apoptosis. Biophys $J$ 2013; 104: 421-431, doi: 10.1016/j.bpj.2012.12.010.

9. Zhao J, Wang SZ, Tang XF, Liu N, Zhao D, Mao ZY. Analysis of thermochemotherapy-induced apoptosis and the protein expressions of $\mathrm{Bcl}-2$ and $\mathrm{Bax}$ in maxillofacial squamous cell carcinomas. Med Oncol 2011; 28 (Suppl 1): S354-S359, doi: 10.1007/s12032-010-9736-4.

10. Thomadaki H, Scorilas A. BCL2 family of apoptosis-related genes: functions and clinical implications in cancer. Crit Rev Clin Lab Sci 2006; 43: 1-67, doi: 10.1080/10408360500295626.

11. Jeon BS, Yoon BI. Altered expression of cellular Bcl-2 in the progression of hamster cholangiocarcinogenesis. Scientific World Journal 2012; 2012: 385840, doi: 10.1100/ 2012/385840.

12. Li J, Shi L, Zhang $X$, Kang $X$, Wen $Y$, Qian $H$, et al. Recombinant adenovirus IL-24-Bax promotes apoptosis of hepatocellular carcinoma cells in vitro and in vivo. Cancer Gene Ther 2010; 17: 771-779, doi: 10.1038/cgt.2010.34.

13. Krajewski S, Krajewska M, Shabaik A, Miyashita T, Wang HG, Reed JC. Immunohistochemical determination of in vivo distribution of Bax, a dominant inhibitor of Bcl-2. Am J Pathol 1994; 145: 1323-1336.

14. Bai $Q H$, Huang GS, Chen XQ. [The expression of Bax gene in mixed cellularity Hodgkin's disease tissue and its implications]. J Fourth Mil Med Univ 1996; 17: 297 (in Chinese).

15. Anvari K, Seilanian TM, Kalantari M, Naseri S, Karimi SM, Ahmadnia $\mathrm{H}$, et al. Expression of $\mathrm{Bcl}-2$ and Bax in advanced or metastatic prostate carcinoma. Urol J 2012; 9: 381-388.
16. Lv YY, Yuan MB. [Expression of bax and bcl-2 and their relationship with cell apoptosis index in human heptocellular carcinoma]. J Shangdong University 2002; 40: 310-311 (in Chinese)

17. Yasumoto J, Takahashi A, Ohnishi K, Ohnishi T. The role of p53 molecule in radiation and hyperthermic therapies. $J$ Health Sci 2003; 49: 273-277, doi: 10.1248/jhs.49.273.

18. Piya S, Kim JY, Bae J, Seol DW, Moon AR, Kim TH. DUSP6 is a novel transcriptional target of p53 and regulates p53mediated apoptosis by modulating expression levels of Bcl2 family proteins. FEBS Lett 2012; 586: 4233-4240, doi: 10.1016/j.febslet.2012.10.031.

19. Guo LL, Cao CA, Xiao S. [A study of Bax expression and its relations with p53 protein expression in hepatocellular carcinoma and adjacent tissues]. China Oncol 1997; 7: 169-170 (in Chinese).

20. Yan SY, Zhang DS, Gu N.The preparation and biocompatibility study on $\mathrm{Fe}_{2} \mathrm{O}_{3}$ magnetic nanoparticles used in tumor hyperthermia. Chinese journal of biomedical engineering 2007; 16: 101-110.

21. Kristjansdottir K, Kim K, Choi JS, Horan TC, Brard L, Moore $R G$, et al. 7 Methyl indole ethyl isothiocyanate causes ROS mediated apoptosis and cell cycle arrest in endometrial cancer cells. Gynecol Oncol 2012; 126: 252-258, doi: 10.1016/j. ygyno.2012.04.041.

22. Steiner E, Kleinhappl B, Gutschi A, Marth E. Analysis of hsp70 mRNA levels in HepG2 cells exposed to various metals differing in toxicity. Toxicol Lett 1998; 96-97: 169176, doi: 10.1016/S0378-4274(98)00065-4

23. Khandhar AP, Ferguson RM, Simon JA, Krishnan KM. Enhancing cancer therapeutics using size-optimized magnetic fluid hyperthermia. J Appl Phys 2012; 111: 7B3067B3063, doi: 10.1063/1.3671427.

24. Schildkopf $P$, Holmer R, Sieber R, Ott OJ, Janko C, Mantel $F$, et al. Hyperthermia in combination with X-irradiation induces inflammatory forms of cell death. Autoimmunity 2009; 42: 311-313, doi: 10.1080/08916930902832041.

25. Yuguchi T, Saito M, Yokoyama Y.Saito T, Nagata T, Sakamoto T, Tsukada K. Combined use of hyperthermia and irradiation cause antiproliferative activity and cell death to human esophageal cell carcinoma cells--mainly cell cycle examination. Hum Cell. 2002; 15(1): 33-42, doi: 10.1111/j. 1749-0774.2002.tb00097.x.

26. Zhang WJ. [Expression of apoptosis-related gene bcl-2 and bax in liver cell carcinoma and its clinical significances]. $J$ Shanxi College Traditional Chinese Medicine 2000; 1: 36-38 (in Chinese).

27. Bian L, He YW, Liang XH, Wang SZ. [Apoptosis induced by hyperthermia and the expressions of $\mathrm{Bcl}-2$ and Bax proteins in maxillofacial squamous cell carcinomas]. J Oral Sci Res 2003; 19: 448-450 (in Chinese).

28. Yonezawa M, Otsuka T, Kato T, Moriyama A, Kato KH, Asai $\mathrm{K}$, et al. Hyperthermic induction of apoptosis in malignant fibrous histiocytoma cells: possible involvement of a p53independent pathway in the induction of bax gene. J Orthop Sci 2002; 7: 117-122, doi: 10.1007/s776-002-8432-4.

29. Matsumoto H, Takahashi A, Wang X, Ohnishi K, Ohnishi T. Transfection of p53-knockout mouse fibroblasts with wildtype p53 increases the thermosensitivity and stimulates 
apoptosis induced by heat stress. Int $\mathrm{J}$ Radiat Oncol Biol Phys 1997; 39: 197-203, doi: 10.1016/S0360-3016(97) 00149-1.

30. Ohnishi T, Wang X, Ohnishi K, Matsumoto H, Takahashi A. p53-dependent induction of WAF1 by heat treatment in human glioblastoma cells. J Biol Chem 1996; 271: 1451014513, doi: 10.1074/jbc.271.24.14510.
31. Oba M, Yano S, Shuto T, Suico MA, Eguma A, Kai H. IFNgamma down-regulates Hsp27 and enhances hyperthermia-induced tumor cell death in vitro and tumor suppression in vivo. Int J Oncol 2008; 32: 1317-1324.

32. Soo ET, Yip GW, Lwin ZM, Kumar SD, Bay BH. Heat shock proteins as novel therapeutic targets in cancer. In vivo 2008; 22: 311-315. 